been positive instead of negative; but if their experiment had not been made, we should have had an uneasy feeling that McDougall's conclusion might after all be justified, although Crew's experiments gave it no support.

The same cause for uneasiness may arise whenever a laborious and difficult investigation has given results which seem to contradict prevailing theories but are not decisive enough to be taken without confirmation. We realize that the experiments must be repeated and that it may be a wearisome business demanding great dexterity, constant attention and the building up of elaborate apparatus. There will be little scope for originality except in the devising of further controls, for the new experiments must not differ appreciably from those they are intended to check. Most of us start with a bias in favour of the orthodox view, and as we know that the pitfalls increase with the length and complexity of the experiment, we shall be surprised if the outcome is not the expected negative. When it turns out that way, we shall be grateful to those who have cleared up our uneasiness, but glad that we could think of adequate reasons for spending our time on something else.

No doubt we shall not have spent our time more profitably. The new experiments usually reveal some unsuspected factor which made the original result misleading, and this factor may be an important clue in different problems. But work of this sort rarely meets with the recognition it deserves, and this is a good opportunity for pointing out that our general advance could not go on without it.

The advance of science must depend on the initiative of those in the front line of research. It must be the aim of each special branch to explore the alleys it has opened up, including those which are most probably blind; but as long as the branches are not controlled from headquarters, their members will decide how this is to be done. Control by head. quarters is sometimes necessary : we cannot demand that we should always be left to choose our own problems, for there are periods when we must all do as we are told, periods of emergency when we are threatened by war or famine or disease and must all join in a concerted attack. In fact, as scientists we have a double responsibility, for our general aim is to advance our understanding of Nature, but we are now the members of a profession which has special responsibilities because of the way in which it can affect the whole structure of civilized life. The immediate claims of society have to be met, and for this we must be willing to do more or less as we are told. For the long-term objectives we can still do better when we are allowed our independence, but only because there are some of us who will face the laborious work when there is no other way of resolving a doubt.

\title{
THE COPLEY MEDAL AND ITS FOUNDER
}

\section{By Engineer-Captain EDGAR C. SMITH, O.B.E., R.N.(Reto.)}

$\mathrm{W}$ HEN in 1773 Sir John Pringle, president of the Royal Society, presented the Copley Medal to Priestley for his "Many Curious and Useful Experiments on Different Kinds of Air", he referred to it as "the palm and laurel of this community". An earlier president, Martin Folkes, when handing the Medal to John Harrison, of chronometer fame, had spoken of it as "this small but faithful token of their regard and esteem". Later, Davy called it "the ancient olive crown of the Royal Society", while Cuvier in his éloge of Priestley wrote: "La Société Royale lui décerna la médaille de Copley, que l'Angleterre considère comme le prix le plus noble auquel on puisse arriver dans les sciences. L'Académie de Paris lui accorda un prix non moins noble, l'une de ces huits places d'associés étrangers". In the eighteenth century there were few scientific societies and still fewer prizes, but to-day, in spite of the great increase in the number of scientific institutions and awards, some of the latter of which are accompanied by large sums of money, the Copley Medal with its honorarium remains what it was to Pringle, Folkes, Davy and Cuvier, although in the press of public affairs its significance is to-day often overlooked.

While this is true, it is fairly certain that few readers know much of its history or of its founder. Ever since 1736 when the first Copley Medal was struck, it has, with some exceptions, been awarded annually, and the long lists of recipients, especially those of the past and present centuries, include the names of many of the greatest men of science who ever lived, no matter what their nationality. A brief account of the founding of the Medal is given in Weld's work, "A History of the Royal Society with
Memoirs of the Presidents compiled from Authentic Documents", published in 1848; but Weld knew little of Copley, and neither did the writer of the notice of him in the "Dictionary of National Biography". Thanks, however, to the researches of Prof. W. H. G. Armytage, of the University of Sheffield, much relating to Copley and his activities has been brought to light, and some of the results are to be found in Prof. Armytage's article entitled "Sir Godfrey Copley, F.R.S., 1653-1709. Some Tercentenary Glimpses through Letters to his Friends", published in Notes and Records of the Royal Society of London (11, No. 1; January 1954). From this it is seen that Copley was a public-spirited man of varied interests and a faithful friend and correspondent.

The exact date of Copley's birth is not known, though evidence points to the year 1653; but it appears certain that he died in Red Lion Square, London, on April 9, 1709, and was buried in the parish church of Sprotborough, about three miles from Doncaster, Yorkshire. He thus lived through the reigns of Charles II, James II and William and Mary, and a part of that of Queen Anne. His father, the first Sir Godfrey, had been made a baronet soon after the restoration by Charles II, and when he died about 1684 his son succeeded to his title and estate, including Sprotborough Hall, then one of the stately homes of England, but now no longer standing. Of Copley's education and upbringing little is known, though he was admitted to Lincoln's Inn in 1674 . Following in his father's footsteps, he served as member of Parliament, first for the little town of Aldborough and then for Thirsk, and was High 


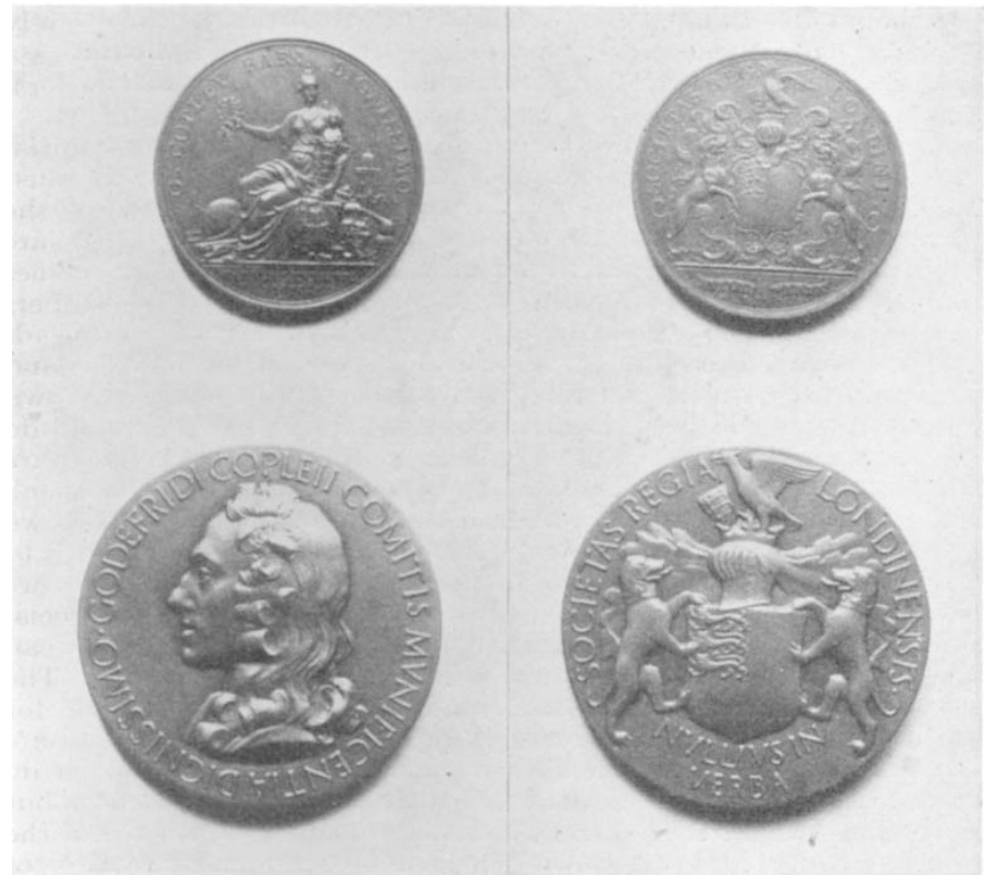

By courtesy of the Royal society

The Copley Medal

ABOVE. Replica of the gold medal awarded to Sir Charles Lyell in 1858. A thena, seated amidst emblems of her own attributes, and of the arts and sciences, holds out in the right hand a wreath; in her left arm is the Ephesian Artemis; on her breast the head of Medusa ; near her the armorial shield of Sir Godfrey Copley. Leg. G. COPLEY BART. DIGNISSIMO. Below, T. (John Sigismund Tanner).

Rev. The armorial shield of the Royal Society, with crest and supporters. Leg. SOCIETAS REG. LONDINI. Ex. On a band the motto NULLIUS IN VERBA. Diameter 17 in ; bronze (replica).

BeLow. New die, first used for the medal awarded in 1941.
Bust of Copley, left, in curly wig. Leg. GODEFRIDI COPLEII COMJ'TS MVNIFI-

Rev. The arms of the Royal Society, with supporters, crest, and motto. Leg. Diameter $2 \cdot 25$ in. ; bronze (replica)

Sheriff of Yorkshire. He was twice married, first to Catherine, daughter of John Purcell, of Nantriba, Montgomeryshire, by whom he had an only daughter, Catherine, and secondly, to Gertrude, daughter of Sir John Carew, of Antony, Cornwall. His daughter became the wife of Joseph Moyle, whose descendants in 1768 assumed the name of Copley and in whose favour the baronetcy was revived ten yoars later. The present representative of the family is Robert Godfrey Wolseley Bewicke-Copley, Baron Cromwell.

As a politician, Copley was assiduous in his attendance at Parliament, and outspoken in his views, as can be seen by his speech against the bill of attainder brought in at the time of the conspiracy of Sir John Fenwick and others : "It is the Custom and Law of our Nation", he declared, "to require two positive witnesses to prove Treason. . . . I look upon it as a fundamental Breach of those Rules, for an accusation to be given in against any Man behind bis Back, by he knows not whom, or by any with whom he is not confronted, and brought Face to Face. ... If this method of Proceeding be warranted by an English Parliament, there is an end to the Defence of any Man living, be he ever so innocent". He was much concemed with the urgent problem of the reform of the currency, a matter which led to Newton's appointment to the Mint, and during the early campaigns of Marlborough he was Comptroller of Army Accounts. Had he lived longer, the world would have heard more of him.
Devoted as he was to his public duties, Copley was no less interested in his native county, embellishing his mansion, improving his gardens and corresponding with and visiting other Yorkshire worthies such as RaIph Thoresby and Thomas Kirke. He tried to improve the navigation of the River Don, was interested in pumping plant, water supply and fountains, and at Sprotborough Hall constructed what was probably the first indoor swimming bath. In a letter to Hans Sloane, he described the bath as being about $34 \mathrm{ft}$. long, $16 \mathrm{ft}$. wide, $6 \mathrm{ft}$. deep and lined with lead. It could be filled to a depth of $4 \frac{1}{2} \mathrm{ft}$. by his water engine in five hours. "Two or three faggots," he added, "and a sack of Coales doth warm it equall to ye heat of your body. . . . My wife and some Ladys of her acquaintance have gone in it together \& are much delighted with it. I am sure this fancy of mine will be followed by some one who perhaps may be willing to outdo me in making one 3 times as large."

Copley's closest friend in London was Hans Sloane, who was seven years his junior and who outlived him forty-four years. Sloane was admitted a Fellow of the Royal Society in 1684 , was secretary of the Society during 16931713 , and in 1727 succeeded Newton as president. Copley was admitted a Fellow in 1691 and six years later was elected a member of Council. He often enjoyed the company of his fellows at one of the coffee houses or at "Pontack's", and his letters contain references to his mathematical books, prints and instruments, to lodestones, air pumps, Napier's Bones, surveying wheels and the voyages of Halley and Middleton. Up to the time of his death, the Royal Society was meeting in the somewhat dilapidated Gresham College, Bishopsgate Street, in the City of London, once the mansion of Sir Thomas Gresham, and it was here the brilliant and vorsatile Hooke was for long curator and demonstrator. In old age, however, he became penurious and in one letter Copley wrote: "Dr. Hooke is very crazy; much concerned for fear he should outlive his estate. He hath starved one old woman already and I believe he will endanger himself to save sixpence for anything he wants ..."; and on March 4, 1702-3, he wrote again : "Your old Philosopher is gone at last, to try experiments with his ancestors. $\mathrm{H}_{\theta}$ is dead, they say, without a will : had only a poor girl with him, who, seeing him ill, went to call somebody; and he was quite gone before they came". In another letter he wrote: "The poor Corporation of London stand in need to make some profit of the ground of Gresham College. I wonder old Dr. Hooke did not choose rather to leave his $12,000 \mathrm{l}$. to continue what he had promoted and studied all the days of his life (I mean mathematical experiments) than to have it go to those whom he never saw or cared for. It is rare that 
Virtuosos die rich, and it is a pity they should if they were like him ....".

It was in the year following Hooke's death that, on October 14, 1704, Copley made the will in which he bequeathed to Hans Sloane and Abraham Hill (1635-1721), F.R.S., the sum of "one hundred pounds, in Trust for The Royal Society of London for improving natural knowledge, to be laid out in experiments, or otherwise, for the benefit thereof, as they shall direct and appoint". Sloane and Hill accordingly dealt with the bequest until Hill's death, after which Sloane was entirely responsible ; and not until he died in 1753 did the Council make the awards. It is thus seen that the early history of the bequest belongs to the time when the Royal Society was meeting in its new quarters in Crane Court, Fleet Street, under the successive presidencies of Newton, Sloane and Folkes.

Though from a letter of Franklin's it appears that the interest on Copley's bequest was being used as early as 1717, the first definite record is a minute of a Council meeting in 1731 which ran: "To Mr. Stephen Gray. For his 'new Electrical Experiments' -as an encouragement to him for the readiness he has always shown in obliging the Society with his discoveries and improvements in this part of Natural Knowledge". A second award was made to Gray in 1732, but in neither case was the amount stated. Gray was a Kentish man who had devoted himself to astronomy and other subjects, but who in 1719 had become a Brother in the ancient Charterhouse, London, the buildings of which are now being restored after being severely damaged during the Second World War. $\mathrm{He}$ was then about sixty-six years of age, and it was within the walls of the Charterhouse, and at the home of his friend, the Rev. Granville Wheler (1701-70), F.R.S., Otterden Place, near Faversham, Kent, that he made that long series of experiments with feathers, hair, silk, wool, soap bubbles, resin and threads which mark an epoch in the early history of electricity. Gray died in 1736, when about eighty-three years of age, and it was later in that year that, at the suggestion of Folkes, the Copley Medal was founded. Made of fine gold and weighing one ounce two pennyweights, it was first presented to the Rev. John Theophilus Desaguliers (1683-1744), whose services as curator and demonstrator to the Society were as valuable as those of Hooke. All subsequent medals were made of gold until 1941, when the medal was redesigned by Mrs. M. Gillick and changed to silver gilt. Of the medals presented in the eighteenth century, the Royal Society possesses that given to Priestley, while the British Museum has those given to Gowin Knight in 1747 and to Sir William Hamilton in 1770 .

There are features in the early history of the Medal before it had attained an international status that are absent in its later story. Altogether, between 1736 and 1800, fifty-nine awards were made; no awards were made on eleven occasions, but duplicate medals were given in 1783 and 1791, while in 1766 no fewer than three were given. It was awarded twice to Desaguliers and twice to Canton, and one of the recipients in 1783 was the nineteen-year-old Yorkshire boy, John Goodricke (1764-86), who in the previous year had discovered the "Period of the Variation of Light in the Star Algol". Among other recipients of the Medal in the eighteenth century were the Rev. Stephen Hales, who lies beneath the tower of Teddington Church, which he restored; Benjamin Robins, the gunnery expert, who died in
India; the Greenwich astronomers, Bradley and Maskelyne; Smeaton; Benjamin Franklin; the wealthy Clapham recluse, Henry Cavendish; Peter Woulfe, "the last true believer in alchemy", whose rooms were as full of furnaces and crucibles as the laboratory of Paracclsus; Captain Cook; John Hunter ; William Herschel ; Rumford; and Volta, who held the chair of physics at Pavia.

With the award of the Medal to Volta in 1794, a new chapter in its history opons, for previously all the recipients had been British citizens, if not of British birth. It was, however, not until 1820, when the Medal was given to the Danish physicist, J. C. Oersted, that the name of another foreigner is found in the list of Medallists. There probably would have been others had it not been for the unfortunate effects of the French Revolution and the Napoleonic Wars. Not long before the signing of the Treaty of Amiens in 1802, the Paris Academy of Sciences elected Banks, Maskelyne, Cavendish, Herschel, l'riestley and Rumford foreign members, but there was no reciprocal action by the Royal Society. The nineteenth century fortunately saw much of the national animosity die away, and in 1825 Arago became the first Frenchman to receive the Medal, in 1836 Berzelius the first Swedish man of science, and in 1838 Gauss the first German. By then the Rumford and Royal Medals had been founded, and some awarded to foreigners, the Royal Society recognizing with impartiality the debt to Continental investi. gators and teachers, to whose laboratories and lecture rooms British students began to flock in increasing numbers.

By the middle of the nineteenth century the Copley Medal had become recognized all the world over as the "palm and laurel" of science, and under the successive presidencies of Sabine, Airy, Hooker, Huxley, Spottiswoode, Stokes and Kelvin, the Society again and again acknowledged the work of other nations. It is thus found that, of the fifty awards made during 1851-1900, no fewer than thirty-two were made to foreigners, the list for the decade 1870-79, for example, including Mayer, Wöhler, Helmholtz, Pasteur, Hofmann, Claude Bernard, J. D. Dana, Boussingault and Clausius. Among the British names found in that half-century are Owen, Darwin, Lyell, Joule, Stokes, Kelvin (then Sir William Thomson) and Lord Rayleigh. To this period also belongs the generous gift in 1881 by the then Sir Joseph Copley of a sum in Consols sufficient to provide an honorarium of $£ 50$ for each medallist. The value of this investment diminishing gradually, the Council of the Society last year made provision for increasing it to $£ 100$.

The present century opened with nothing to disturb the relations of men of science of either Europe or America, and under the presidency of Sir William Huggins, himself a Copley medallist, the Medal was awarded in turn to Willard Gibbs of America, Lord Lister, the Austrian geologist Suess, Sir William Crookes and the Russian chemist Mendeléeff. Next in the list come the names of Metchnikoff, Michelson, A. R. Wallace, G. W. Hill, Galton, Sir George Darwin, Prof. Klein of Göttingen, Ray Lankester and Sir J. J. Thomson, to whom it was: given in 1914. With the outbreak of war and the upheavals of the past forty years, the Royal Society was faced with difficulties similar to those of the days of Napoleon, and once again British names appear with greater frequency, as can be seen from the following table: 


$\begin{array}{lr}\text { Copley } & \text { Medalists, 1915-54 } \\ 1915 \text { I. P. Pavlov } & 1934 \text { Prof. J. S. Haldane } \\ 1916 \text { Sir. James Dewar } & 1935 \text { Prof. C. T. R. Wilson } \\ 1917 \text { Emile Roux } & 1936 \text { Sir Arthur Evans } \\ 1918 \text { H. A. Lorentz } & 1937 \text { Sir Henry Dale } \\ 1919 \text { W. M. Bayliss } & 1938 \text { Prof. Niels Bohr } \\ 1920 \text { H. T. Brown } & 1939 \text { Prof. T. H. Morgan } \\ 1921 \text { Sir Joseph Larmor } & 1940 \text { Prof. P. Langevin } \\ 1922 \text { Lord Rutherford } & 1941 \text { Sir Thomas Lewis } \\ 1923 \text { Sir Horace Lamb } & 1942 \text { Sir Robert Robinson } \\ 1924 \text { Sir Edward Sharpey- } & 1943 \text { Sir Joseph Bancroft } \\ \text { Schafer } & 1944 \text { Sir Geoffrey Taylor } \\ 1925 \text { A. Einstein } & 1945 \text { Dr. O. T. Avery } \\ 1926 \text { Sir Frederick Gow- } & 1946 \text { Dr. E. D. Adrian } \\ \text { land Hopkins } & 1947 \text { Prof. G. H. Hardy } \\ 1927 \text { Sir Charles Sherring- } & 1948 \text { Prof. A. V. Hill } \\ \text { ton } & 1949 \text { Prof. G. C. de Hevesy } \\ 1928 \text { Sir Charles Parsons } & 1950 \text { Sir James Chadwick } \\ 1929 \text { Prof. Max Planck } & 1951 \text { Prof. D. Keilin } \\ 1930 \text { Sir William Bragg } & 1952 \text { Prof. P. A. M. Dirac } \\ 1931 \text { Sir Arthur Schuster } & 1953 \text { Prof. A. J. Kluyver } \\ 1932 \text { Dr. G. E. Hale } & 1954 \text { Sir Edmund Whit- } \\ 1933 \text { Prof. T. Smith } & \text { taker }\end{array}$

Whatever the conclusions of a reader may be, it is, however, well to remember the lines,

"This world is not for aye; nor 'tis not strange

That even our love should with our fortunes change..."

and in spite of contending political systems and of national prejudices, no man of science will dispute the remark of Davy's that "Science like Nature, to which it belongs is neither limited by time or space. It belongs to the world and is of no country and no age".

\section{OBITUARIES}

\section{Prof. A. F. Blakeslee}

Prof. Albert Francis Blakeslee, of Smith College, Northampton, Massachusetts, died on November 16 at the age of eighty. Blakeslee will perhaps be remembered as a man who made more varied discoveries than any biologist of his time. Fifty years ago he observed that sexual reproduction in fungi was restricted by a genetic incompatibility, a principle which is now known to limit and direct sexual reproduction in plants and in the lower organisms generally. Thirty years ago in a large series of collaborative studies on Datura he began to show a whole unexpected range of chromosome changes (polyploidy, interchange, etc.) underlying the variation of the species. He pursued this work with unremitting zeal throughout his life. But concurrently he was showing how polyploidy could be induced in innumerable plants with the help of colchicine and he was investigating the genetics of the faculties of taste and smell in man as well as of fragrance in the plant itself. At the age of seventysix, still a guest professor at Smith College, he attended the Stockholm Botanical Congress and gave papers on the chromosomes of species hybrids in Datura, on the use of chimæras in elucidating the germ layers of plants, on the culture of excised embryos as a means of growing inviable hybrids, and on the development of Rudbeckia hirta by selection from a wild species to a garden plant.

These were only the more successful inquiries that Blakeslee undertook. His energy and curiosity took him into many less productive fields. Two things strike one about his work. One is that he never made any serious mistake of observation. The other is that he never ventured far into interpretation or prediction after his early studies in fungi. Here his interpretation was unfortunate in that he tied the word sex to the property of incompatibility and thereby led his successors astray right down to the present day. In a sense the style of his work is best represented by his diagrams of Datura chromosomes as packets. These diagrams were useful in a popular sense so long as one did not take them too seriously. Unfortunately, it seems that Blakeslee did take them seriously. To him they were the real and final thing.

By his alertness and ingenuity and his practical sense in organizing the Station for Experimental Evolution at Cold Spring Harbor (where he worked for thirty years, until his retirement in 1942), Blakeslee kept the botanical world of his day in a state of constant stimulation. C. D. DarLington

\section{Dr. Neville Jones, O.B.E.}

Neville Jones, whose death on October 24 has been reported from Bulawayo, was a pioneer in Rhodesian prehistory, and during the years 1913-47 worked out the complete succession of Stone Age cultures in the western part of Southern Rhodesia.

Born in London in 1880, he was educated at Dulwich College and, after working in various capacities, including an appointment as geologist to an expedition to Madagascar in 1906-7, he went to Southern Rhodesia as a missionary in 1912. On retiring from mission work at the age of fifty-five, be at once commenced a new profession and became the first keeper of prehistory at the National Museum of Southern Rhodesia in Bulawayo. Here he was able to devote his whole time to prehistory, and his best scientific work was done during the twelve years in which he held his Museum post.

Important as was his work on the Stone Age, it was by no means his only interest. As a missionary among the Matabele, he saw much of these people and published anthropological notes as well as a valuable historical study, "My Friend Kumalo" (1945). With one very important exception, his field-studies related to the Stone Age; but the exception, the excavation of Mapungubwe in the Northern Transvaal in 1934, shows that Stone Age studies were not all-absorbing for him. His work at this site is incorporated in Prof. Fouche's "Mapungubwe" (1937). Besides his archæologicel work, he was a botanist and entomologist of no mean calibre, being especially interested in the collection and culture of South African xerophytic plants.

Jones was the moving spirit in the foundation of the Commission for the Preservation of Natural and Historical Monuments and Relics in Southern Rhodesia and was successively its secretary and its chairman.

His lack of formal academic qualifications never greatly worried him, for his wide correspondence enabled him to keep in touch with current thought in his subject; nevertheless, the honorary doctorate conferred upon him by the University of the Witwatersrand during the last year of his life was the most highly prized of his honours.

Jones's work for prehistory will provide a basis which other workers, who knew him not, will accept or, perchance, reject; to his colleagues throughout Southerm Africa he has, however, left a personal legacy in his example of quiet, careful and unselfish work for which they are all the richer.

\section{R. SUMMERS}

